\title{
PENGARUH MOTIVASI DAN DISIPLIN KERJA TERHADAP KINERJA KARYAWAN BPJS KETENAGAKERJAAN BEKASI KOTA
}

\author{
Muhammad Amien Firdaus ${ }^{1)}$ \\ 1) Mahasiswa Program Studi Manajemen FE UNKRIS \\ Ella Siti Chaeriah 2) \\ 2) Dosen Program Studi Manajemen FE UNKRIS \\ Alamat: Kampus UNKRIS, Jatiwaringin Jakarta Timur \\ Email : ellasiti.unkris@gmail.com
}

\begin{abstract}
The purpose of this study is to analyze the effect of motivation and work discipline on employee performance of BPJS Ketenagakerjaan Bekasi Kota. This research is included in the category of causal associative research using a quantitative approach. The population in this study were all employees of the BPJS Ketenagakerjaan Bekasi Regional Office, totaling 46 people and all of them were sampled, because the numbers were relatively small. Methods of data analysis using partially and simultaneous linear regression. The results showed that partially and simultaneous motivation and work discipline had a positive and significant effect on employee performance of BPJS Ketenagakerjaan Bekasi Kota.
\end{abstract}

Keywords: Motivation, work discipline and employee performance

\section{PENDAHULUAN}

Dunia bisnis sekarang dituntut menciptakan kinerja karyawan yang tinggi, pengembangan perusahaan. Perusahaan harus mampu membangun dan meningkatkan kinerja di dalam lingkungannya. Keberhasilan perusahaan tersebut dipengaruhi oleh beberapa faktor, salah satu faktor penting adalah sumber daya manusia, karena sumber daya manusia merupakan pelaku dari keseluruhan tingkat perencanaan sampai dengan evaluasi yang mampu memanfaatkan sumber daya-sumber daya lainnya yang dimiliki oleh organisasi atau perusahaan. Keberadaan sumber daya manusia di dalam suatu perusahaan memegang peranan yang sangat penting. Tenaga kerja memiliki pengaruh yang besar untuk menjalankan aktivitas perusahaan.

Meningkatkan kinerja karyawannya perusahaan menempuh beberapa cara misalnya melalui pendidikan, pelatihan, pemberian kompensasi yang layak, menciptakan lingkungan kerja dan disiplin kerja yang kondusif dan pemberian motivasi. Melalui prosesproses tersebut, karyawan diharapkan akan lebih memaksimalkan tanggung jawab atas pekerjaan mereka. Karena para karyawan telah terbekali oleh pendidikan dan pelatihan yang tentu berkaitan dengan implementasi kerja karyawan, sedangkan pemberian kompensasi, disiplin kerja yang baik serta pemberian motivasi pada dasarnya adalah hak para karyawan dan merupakan kewajiban dari pihak perusahaan untuk mendukung kontribusi para karyawannya dalam rangka mencapai tujuan yang telah ditentukan.

Setiap anggota dari suatu organisasi mempunyai kepentingan dan tujuan sendiri ketika ia bergabung pada 
organisasi tersebut. Bagi sebagian karyawan, harapan untuk mendapatkan uang adalah satu-satunya alasan untuk bekerja, namun yang lain berpendapat bahwa uang hanyalah salah satu dari banyak kebutuhan yang terpenuhi melalui kerja. Seseorang yang bekerja akan merasa lebih dihargai oleh masyarakat di sekitarnya, dibandingkan yang tidak bekerja. Untuk menjamin tercapainya keselarasan tujuan, pimpinan organisasi bisa memberikan perhatian yang lebih dengan memberikan motivasi, karena motivasi merupakan bagian dari hubungan timbal balik antara organisasi dengan sumber daya manusia.

Dalam rangka mempertahankan perusahaan dengan adanya persaingan global, maka aktivitas didalam perusahaan harus didukung oleh faktor motivasi dan disiplin kerja sehingga dapat meningkatkan kinerja. Salah satu faktor kinerja adalah manusia, manusia merupakan tenaga kerja dalam perusahaan untuk menghasilkan barang dan jasa. Kinerja karyawan yang tinggi akan berdampak pada kelangsungan hidup perusahaan, dan tentunya harapan yang ingin dicapai suatu perusahaan adalah tujuan yang direncanakan akan dapat terpenuhi. Kinerja merupakan suatu hasil kerja secara kualitas dan kuantitas yang dicapai seorang pegawai dalam melaksanakan fungsinya sesuai dengan tanggung jawab yang diberikan kepadanya. Penampilan hasil karya tidak terbatas kepada personil yang memangku jabatan fungsional maupun struktural tetapi juga kepada keseluruhan jajaran personil di dalam organisasi.

Dari sudut pandang perusahaan, pemberian motivasi atau semangat kerja merupakan suatu daya gerak yang mendorong seseorang untuk berbuat sesuatu dan motivasi adalah kegiatan untuk memberikan dorongan kepada seseorang atau diri sendiri untuk mengambil suatu tindakan yang dikehendaki. Timbulnya motivasi pada diri seseorang tentu didorong oleh adanya suatu kebutuhan hidup baik itu kebutuhan primer maupun kebutuhan sekunder. Jika kebutuhan tersebut dapat terpenuhi, maka seseorang akan giat bekerja sehingga kinerja dapat meningkat sesuai dengan keinginan organisasi (Sedarmayanti, 2015). Suatu organisasi harus memberikan motivasi kepada karyawannya. Salah satu faktor yang dirasakan sangat penting di dalam penentuan keberhasilan serta kelangsungan hidup organisasi adalah tingkat kemampuan dan keterampilan dari para karyawannya. Kenyataannya tidak semua karyawan memiliki kriteria sesuai dengan harapan dan juga terdapatnya pekerja yang memiliki kemampuan dan keterampilan yang tinggi, tetapi tidak memiliki semangat kerja yang tinggi, maka dengan demikian organisasi tersebut belum dapat memberikan motivasi kepada karyawan untuk menciptakan kualitas kerja yang baik yang sesuai dengan harapan perusahaan agar tercipta hubungan timbal balik yang menguntungkan antara karyawan dan perusahaan.

Di sisi lain sejalan dengan motivasi, disiplin kerja juga merupakan hal penting yang harus menjadi perhatian organisasi/perusahaan. Disiplin adalah kesadaran dan kesediaan seseorang menaati peraturan semua perusahaan dan norma-norma sosial yang berlaku. Adapun arti kesadaran adalah sikap seseorang yang secara sukarela mentaati semua peraturan dan sadar akan tugas dan tanggung jawabnya. Sedangkan arti kesediaan adalah suatu sikap, tingkah laku, dan perbuatan seseorang yang sesuai dengan peraturan perusahaan baik tertulis maupun tidak.

Disiplin terutama ditinjau dari perspektif organisasi, dapat dirumuskan sebagai ketaatan setiap anggota organisasi terhadap semua aturan yang berlaku di dalam organisasi tersebut, yang terwujud melalui sikap, perilaku 
dan perbuatan yang baik sehingga tercipta keteraturan, keharmonisan, tidak ada perselisihan, serta keadaan-keadaan baik lainnya. Kedisiplinan adalah kunci keberhasilan suatu organisasi dalam mencapai tujuannya. Dengan disiplin yang baik berarti karyawan sadar dan bersedia mengerjakan semua tugasnya dengan efektif dan efisien sehingga para karyawan dapat mencapai prestasi kerja yang tinggi. Perilaku karyawan yang tidak disiplin dapat diekspresikan dalam beberapa hal; yaitu: keabsenan, kelambanan, meninggalkan tempat kerja, mengulangi prestasi buruk, mencuri, tidur ketika kerja, berkelahi, mengancam pimpinan, melanggar aturan dan kebijaksanaan keselamatan kerja, pembangkangan perintah, melakukan pelanggaran secara tidak wajar, memperlambat pekerjaan, menolak kerja lembur, menolak kerja sama dengan rekan, memiliki dan menggunakan obatobatan ketika bekerja, merusak peralatan, menggunakan bahasa atau kata-kata kotor dan pemogokan secara ilegal.

Untuk meningkatkan kinerja karyawan adalah perusahaan perlu memberikan motivasi dan memperhatikan disiplin kerja kepada seluruh karyawannya. Kinerja merupakan tingkat pencapaian hasil atas pelaksanaan tugas tertentu. Kinerja juga dapat dipandang sebagai proses tentang bagaimana pekerjaan berlangsung untuk mencapai hasil kerja. Namun, hasil pekerjaan itu sendiri menunjukkan kinerja. Kinerja di dalam organisasi dilakukan oleh segenap sumber daya manusia dalam organisasi, baik unsur pimpinan maupun pekerja. Banyak faktor yang dapat mempengaruhi sumber daya manusia dalam menjalankankan kinerjanya. Terdapat faktor yang berasal dari luar maupun dari dalam dirinya. Kinerja karyawan bukanlah suatu kebutuhan saja, tetapi banyak faktor yang mempengaruhi diantaranya pemberian motivasi dan rangsangan yang sesuai.
Kinerja karyawan yang optimal, dapat dicapai jika didahului dengan perbuatan yaitu melaksanakan tugas yang dibebankan. Para karyawan akan lebih termotivasi untuk lebih bertanggung jawab atas pekerjaan mereka, apabila perusahaan mengerti dan memperhatikan betul akan kebutuhan para karyawannya, yang pada dasarnya adalah mereka bekerja untuk mendapatkan uang, dalam hal ini berbentuk gaji.

PT. BPJS Ketenagakerjaan (Persero) merupakan perusahaan yang bergerak pada bidang jaminan sosial tenaga kerja yang dalam naungan BUMN (Badan Usaha Milik Negara), sampai saat ini PT. BPJS Ketenagakerjaan tidak hanya memiliki program untuk bermanfaat bagi karyawan dan perusahaan tetapi juga berperan aktiv dalam meningkatkan pertumbuhan perekomomian bagi kesejahtraan masyarakat. BPJS ketenagakerjaan yang merupakan salah satu badan hukum publik di Indonesia yang bertugas menyelenggarakan jaminan sosial untuk seluruh tenaga kerja di Indonesia. Visi BPJS Ketenagakerjaan adalah menjadi badan penyelenggara jaminan sosial kebanggan bangsa, yang amanah, bertata kelola baik serta unggul dalam operasional dan pelayanan. Pemberian manfaat yang digunakan untuk meningkatkan kesejahteraan tenaga kerja peserta BPJS Ketenagakerjaan dan atau keluarganya, serta membantu badan atau unit usaha yang mempunyai keterkaitan langsung dengan peningkatan kesejahteraan pekerja. Untuk mencapai visi tersebut, harus dimulai dari sumber daya manusia yang adadi BPJS Ketenagakerjaan. Hal tersebut dikarenakan sumber daya merupakan salah satu hal terpenting di sebuah perusahaan. Sumber daya manusia yang memiliki kualitas dan kinerja yang baik akan menghasilkan kinerja yang berkualitas puladalam pencapaian target yang telah ditentukan 
perusahaan. Sebuah perusahaan tidak akan berhasil mencapai tujuannya jika karyawan tidak bekerja denganbaik dan optimal.

Berdasarkan pengamatan yang dilakukan di kantor BPJS Ketenagakerjaan Cabang Bekasi Kota bahwa BPJS Ketenagakerjaan mencanangkan konsep Friendly Service. Konsep ini, merupakan salah satu milestone BPJS Ketenagakerjaan untuk mempercepat upaya menuju organisasi yang menerapkan konsep World Class Service. Konsep Friendly Service adalah sebuah sistem pelayanan yang mengarah pada implementasi e-Service di seluruh Kantor Cabang, meraih penghargaan pelayanan publik, pelayanan e-payment dan e-report, pengembangan SLA layanan dan penanganan pengaduan, empowering case manager, implementasi Program JKK-RTW dan JHT, JK dan Jaminan Pensiun.

BADAN Penyelenggara Jaminan Sosial Ketenagakerjaan (BPJS-TK) cabang Bekasi Kota mulai masif memanfaatkan teknologi Informasi dalam melayani masyarakat. Melalui aplikasi BPJSTKU di ponsel berbasis andriod dan website bpjsketenagakerjaan.go.id, petugas akan melayani masyarakat dalam mengurus proses klaim Jaminan Hari Tua (JHT). Layanan online menawarkan banyak keuntungan bagi masyarakat seperti menghemat uang, waktu dan tenaga karena tidak perlu datang ke kantor pengelola. Peserta, cukup membuka laman resmi di kanal yang disediakan dan memilih menu pengajuan klaim.

Setelah jenis klaim dipilih, peserta akan diminta mengunggah data-data yang diperlukan seperti KTP, Kartu Keluarga, Surat Keterangan Kerja dan dokumen lainnya," Sosialisasi tentang pemanfaatan teknologi ini sering disampaikan kepada masyarakat. Terakhir kali lembaganya memaparkan akses ini kepada 100 perusahaan yang berdomisili di Kota
Bekasi. "Pemanfaatan teknologi ini dilatarbelakangi adanya peserta yang kesulitan dan mengalami kendala, terutama masalah administrasi kelengkapan dokumen.

Layanan yang disediakan ini tidak berbelit. Setelah berkas dinyatakan lengkap melalui proses verifikasi, maka peserta akan mendapatkan balasan melalui email. Balasan itu, berisi tentang jadwal datang ke kantor BPJS Ketenagakerjaan di Jalan Pramuka, Bekasi Selatan untuk proses selanjutnya. Setelah selesai, maka proses klaim JHT paling lambat dua hari melalui transfer rekening bank peserta. Pelayanan manual masih dilayani, tapi untuk menghindari antrean banyak, maka dibuat antrean online. Namun, resiko klaim manual berada di kelengkapan administrasi, jika kurang maka akan diminta melengkapi, dan ini membutuhkan waktu lagi. Berdasarkan catatannya, jumlah peserta BPJS Ketenagakerjaan yang melakukan klaim JHT mencapai 150 orang setiap hari dari total peserta BPJS-TK di Kota Bekasi mencapai 320.000 peserta.

Sesuai peraturan yang baru, proses klaim JHT tak perlu menunggu waktu lama, begitu peserta sudah keluar dari perusahaan, maka bisa mengajukan klaim JHT. JHT adalah tabungan peserta. Nilai yang disetorkan setiap bulan sebesar 5,7 persen dari nilai gaji. Rinciannya dua persen ditanggung peserta, dan 3,7 persen ditanggung oleh perusahaan tempat bekerja. Begitu besarnya peranan pegawai di BPJS ketenagakerjan dan untuk memotivasi mereka dalam meningkatkan kinerja tentunya untuk hal ini pemberian kompensasi memiliki peranan yang sangat besar. Namun dengan adanya perubahan dalam system pemberian kompensasi menjadi ketidakpuasan bagi sebagian pegawainya terutama perubahan dalam pemberian bonus yang dulu sangat mudah mendapatkan banyak bonus dilihat dari lamanya bekerja, tetapi prasyarat 
sekarang untuk mendapatkan bonus mereka harus bekerja keras mencapai target dan tidak melihat dari lamanya kerja.

Tujuan penelitian ini adalah untuk mengetahui pengaruh motivasi dan disiplin kerja terhadap kinerja karyawan BPJS Ketenagakerjaan Bekasi Kota.

\section{LANDASAN TEORI}

\section{Motivasi}

$\begin{array}{lrr}\text { Pentingnya motivasi } & \text { karena } \\ \text { motivasi merupakan hal yang } \\ \text { menyebabkan, menyalurkan }\end{array}$ mendukung perilaku manusia. Supaya mau bekerja giat dan antusias mencapai hasil yang memuaskan, motivasi semakin penting karena atasan membagikan pekerjaan kepada bawahannya untuk dikerjakan dengan baik dan teritegrasi kepada tujuan yang diinginkan.

Menurut McClelland, dalam Mangkunegara (2017), bahwa: "Motivasi merupakan Kondisi jiwa yang mendorong seseorang dalam mencapai prestasinya secara maksimal." Selanjutnya Rivai (2014), mengatakan bahwa: "Motivasi merupakan serangkaian sikap dan nilai-nilai yang mempengaruhi individu untuk mencapai hal yang spesifik sesuai dengan tujuan individu." Serta pendapat Hasibuan (2017), bahwa: Motivasi kerja adalah "pemberian daya penggerak yang menciptakan kegairahan kerja seseorang agar mereka mau bekerja sama, bekerja efektif, dan terintegrasi dengan segala daya upayanya untuk mencapai kepuasan." Kemudian menurut Robbins dan Judge (2008), motivasi sebagai "proses yang menjelaskan intensitas, arah dan ketekunan seorang individu untuk mencapai tujuannya".

Dengan pengertian di atas disimpulkan bahwa motivasi kerja merupakan suatu keadaan yang ada dalam diri setiap orang yang memiliki keinginan untuk melakukan hal yang menyebabkan, menyalurkan dan mendukung perilaku manusia agar mau bekerja giat untuk mencapai tujuan.

Ada beberapa teori motivasi yang dikemukakan oleh ilmuwan yang menekuni kegiatan pengembangan teori motivasi. Berikut beberapa teori motivasi: 1). Teori Abraham Maslow; Kebutuhan dapat didefinisikan sebagai suatu kesenjangan atau pertentangan yang dialami antara suatu kenyataan dengan dorongan yang ada dalam diri. Kebutuhan merupakan fundamen yang mendasari perilaku karyawan. Kita tidak akan bisa memotivasi karyawan jika kebutuhan karyawan belum bisa terpenuhi oleh perusahaan. Pemenuhan motivasi harus sesuai dengan kebutuhan yang diinginkan oleh karyawan. Maslow melihat adanya kebutuhan yang harus dipenuhi oleh karyawan. Maslow, mengemukakan bahwa hirarki kebutuhan manusia adalah sebagai berikut: a). Kebutuhan fisiologis, yaitu kebutuhan untuk makan, minum, perlindungan fisik, bernafas, seksual. Kebutuhan ini merupakan kebutuhan tingkat terendah atau disebut pula sebagai kebutuhan yang paling dasar. b). Kebutuhan akan harga diri, adalah kebutuhan untuk dihormati dan dihargai oleh orang lain. c). Kebutuhan untuk mengaktualisasikan diri, yaitu kebutuhan untuk menggunakan kemampuan, skill, dan potensi. Kebutuhan untuk berpendapat dengan mengemukakan ide-ide memberi penilaian dan kritik terhadap sesuatu. 2). Teori Dua Faktor Herzberg; Teori ini dikembangkan oleh Hezberg, teori ini juga menggunakan teori Maslow sebagai titik acuannya. Hezberg melakukan penelitian dengan cara melakukan wawancara. Masing-masing responden diminta untuk menceritakan sesuatu yang terjadi entah itu yang menyenangkan (memberikan kepuasan) ataupun tidak menyenangkan.atau yang tidak memberikan kepuasan. Kemudian hasil wawancara itu dianalisis dengan 
menggunakan analisis isi untuk menentukan mana faktor yang memberikan kepuasan atau yang tidak memberikan kepuasan. Herzberg dalam Hasibuan (2017), menyatakan ada tiga hal penting yang harus diperhatikan dalam memotivasi karyawan yaitu: a). Hal-hal yang mendorong karyawan adalah "pekerjaan yang menantang yang mencakup perasaan untuk berprestasi, bertanggung jawab, kemajuan dapat menikmati pekerjaan itu sendiri dan adanya pengakuan atas semuanya itu. b). Hal-hal yang mengecewakan karyawan adalah terutama faktor yang bersifat embel-embel saja pada pekerjaan, peraturan pekerjaan, penerangan, istirahat, sebutan jabatan, hak, gaji, tunjangan, dan lain-lainnya. c). Karyawan kecewa, jika peluang untuk berprestasi terbatas. Mereka akan menjadi sensitif pada lingkungannya serta mulai mencaricari kesalahan. 3). Teori Motivasi Berprestasi McClelland; McClelland, mengemukakan bahwa produktivitas seseorang sangat ditentukan oleh "virus mental" yang ada pada dirinya. Virus mental adalah kondisi jiwa yang mendorong seseorang yang mampu mencapai prestasinya secara maksimal. Virus mental yang dimaksud terdiri dari 3 dorongan kemampuan, yaitu: a). Kebutuhan untuk berprestasi. b). Kebutuhan untuk memperluas pergaulan. c). Kebutuhan untuk menguasai sesuatu. Berdasarkan teori McClelland tersebut sangat penting dibinanya virus mental manajer dengan cara mengembangkan potensi mereka melalui lingkungan kerja secara efektif agar terwujudnya produktifitas perusahaan yang berkualitas tinggi dan tercapainya tujuan utama organisasi".

Ada beberapa tujuan yang diperoleh dari pemberian motivasi menurut Hasibuan (2017), yaitu: 1). "Meningkatkan moral dan kepuasan kerja karyawan. 2). Meningkatkan produktivitas kerja karyawan.
3). Mempertahankan kestabilan karyawan perusahaan. 4). Meningkatkan disiplin karyawan. 5). Mengefektifkan pengadaan karyawan. 6). Menciptakan suasana dan hubungan kerja yang baik. 7). Meningkatkan loyalitas, kreatifitas dan partisipasi karyawan. 8). Meningkatkan tingkat kesejahteraan karyawan. 9). Mempertinggi rasa tanggung jawab karyawan terhadap tugas - tugasnya. 10). Meningkatkan efisiensi penggunaan alat - alat dan bahan baku".

Menurut Herzberg dalam Siagian (2012), bahwa karyawan termotivasi untuk bekerja disebabkan oleh dua faktor, yaitu: 1). "Faktor Instrinsik yaitu faktor daya dorong yang timbul dari dalam diri masing-masing karyawan, berupa pekerjaan itu sendiri, kemajuan, tanggung jawab, pengakuan, dan pencapaian. 2). Faktor Ekstrinsik yaitu faktor pendorong yang datang dari luar diri seseorang terutama dari organisasi tempatnya bekerja, berupa administrasi dan kebijakan perusahaan, penyeliaan, gaji, hubungan antar pribadi dan kondisi kerja".

Menurut Maslow yang dikutip Hasibuan (2017), menjelaskan bahwa motivasi kerja karyawan dipengaruhi oleh beberapa indikator antara lain: 1). "Fisioligis atau kebutuhan fisik, ditunjukkan dengan pemberian gaji yang layak kepada pegawai, pemberian bonus, uang makan, uang transportasi, fasilitas perumahan dan lain sebagainya. 2). Keamanan, ditunjukkan dengan fasilitas keamanan dan keselamatan kerja yang diantaranya seperti adanya jaminan sosial tenaga kerja, dana pensiun, tunjangan kesehatan, asuransi kesehatan, dan perlengkapan keselamatan kerja. 3). Sosial, ditunjukkan dengan melakukan interaksi dengan orang lain yang diantaranya dengan menjalin hubungan kerja yang harmonis, kebutuhan untuk diterima dalam kelompok dan kebutuhan untuk mencintai dan dicintai. 4). Penghargaan, 
ditunjukkan dengan pengakuan dan penghargaan berdasarkan kemampuan, yaitu kebutuhan untuk dihormati dan dihargai oleh karyawan lain dan pimpinan terhadap prestasi kerjanya. 5). Aktualisasi diri, ditunjukkan dengan sifat pekerjaan yang menarik dan menantang, dimana karyawan tersebut akan mengerahkan kecakapannya, kemampuan, ketrampilan dan potensinya. Dalam pemenuhan kebutuhan ini dapat dilakukan oleh perusahaan dengan menyelenggarakan pendidikan dan pelatihan".

\section{Disiplin Kerja}

Disiplin kerja adalah "suatu sikap menghormati, menghargai, patuh, dan taat terhadap peraturan-peraturan yang berlaku, baik yang tertulis maupun tidak tertulis serta sanggup menjalankannya dan tidak mengelak untuk menerima sanksi-sanksinya apabila ia melanggar tugas dan wewenang yang diberikan kepadanya”. (Sastrohadiwiryo, 2012). Menurut Nitisemitro (2010), disiplin kerja adalah "suatu sikap, tingkah laku, dan perbuatan yang sesuai dengan peraturan organisasi perusahaan, baik yang tertulis maupun yang tidak tertulis". Selanjutnya menurut Mathis \& Jackson (2012), Disiplin merupakan "bentuk pelatihan yang menegakkan peraturanperaturan perusahaan dan memberi kepercayaan untuk menjalankan pekerjaannya secara efektif". Disiplin juga merupakan "salah satu fungsi manajemen sumber daya manusia yang penting dan merupakan kunci terwujudnya tujuan, karena tanpa adanya disiplin maka sulit mewujudkan tujuan yang maksimal". (Sedarmayanti, 2015). Melalui disiplin pula timbul keinginan dan kesadaran untuk menaati peraturan organisasi dan norma sosial. Namun tetap pengawasan terhadap pelaksanaan disiplin tersebut perlu dilakukan.

Dari beberapa pendapat itu dapat disimpulkan bahwa disiplin kerja adalah sikap ketaatan dan kesetiaan seseorang/sekelompok orang terhadap peraturan tertulis/ tidak tertulis yang tercermin dalam bentuk tingkah laku dan perbuatan pada suatu organisasi untuk mencapai suatu tujuan tertentu.

Secara umum tujuan utama disiplin kerja adalah demi kelangsungan organisasi atau perusahaan sesuai dengan motif organisasi atau perusahaan yang bersangkutan baik hari ini maupun hari esok. Menurut Sastrohadiwiryo (2012), secara khusus tujuan disiplin kerja para pegawai, antara lain: 1). "Agar para pegawai menepati segala peraturan dan kebijakan ketenagakerjaan maupun peraturan dan kebijakan organisasi yang berlaku, baik tertulis maupun tidak tertulis, serta melaksanakan perintah manajemen dengan baik. 2). Agar pegawai dapat melaksanakan pekerjaan dengan sebaik-baiknya serta mampu memberikan pelayanan yang maksimum kepada pihak tertentu yang berkepentingan dengan organisasi sesuai dengan bidang pekerjaan yang diberikan kepadanya. 3). Agar pegawai dapat menggunakan dan memelihara sarana dan prasarana, barang dan jasa organisasi dengan sebaik-baiknya. 4). Para pegawai dapat bertindak dan berpartisipasi sesuai dengan norma-norma yang berlaku pada organisasi. 5). Pegawai mampu menghasilkan produktivitas yang tinggi sesuai dengan harapan organisasi, baik dalam jangka pendek maupun jangka panjang".

Ada beberapa faktor yang mempengaruhi tingkat kedisiplinan karyawan menurut Hasibuan, (2017), yaitu: 1). "Teladan Pimpinan, yaitu sosok pimpinan atau atasan yang sikap dan perilakunya dapat dijadikan contoh oleh bawahan atau karyawannya. 2). Balas Jasa, yaitu besarnya imbalan yang diterima karyawan sesuai dengan pekerjaannya, sehingga mereka merasa puas dan dapat hidup layak. 3). Keadilan, yaitu pimpinan dalam memimpin harus 
bersikap adil terhadap semua bawahannya baik berupa pemberian balas jasa maupun sanksi. 4). Waskat (Pengawasan Melekat), yaitu kebersamaan aktif antara atasan dengan bawahan dalam mencapai tujuan perusahaan, karyawan, dan masyarakat. 5). Sanksi Hukuman, yaitu penerapan sanksi berdasarkan pertimbangan logis, masuk akal, dan diinformasikan secara jelas kepada semua karyawan. 6). Ketegasan, yaitu pimpinan menegur dan menghukum setiap karyawan yang indisipliner. 7). Hubungan Kemanusiaan, yaitu hubungan yang baik antara atasan dengan bawahan sehingga tercipta situasi kerja yang kekeluargaan".

Menurut Moenir (2010), indikatorindikator yang mempengaruhi disiplin kerja: 1). "Ketepatan waktu; Ketepatan waktu dalam pekerjaan dan tugas, meliputi : a). Ketepatan waktu dalam melaksanakan tugas. b). Penghematan waktu dalam melaksanakan tugas. 2). Tanggungjawab; Tanggungjawab dalam pekerjaan dan tugas, meliputi: a). Melakukan pekerjaan sesuai dengan rencana. b). Mengevaluasi hasil pekerjaan. c). Keberanian menerima resiko kesalahan. 3). Ketaatan; Ketaatan terhadap peraturan yang telah ditetapkan, meliputi : a). Ketaatan terhadap jam kerja. b). Ketaatan terhadap pimpinan. c). Ketaatan terhadap prosedur dan metode kerja".

\section{Kinerja Karyawan}

Kinerja pada dasarnya memiliki banyak arti berdasarkan sudut pandang atau pendapat para ahli. Menurut Gibson (2008), kinerja adalah "hasil dari suatu perilaku seseorang atau kelompok yang terkait dengan cara kerjanya". Pada setiap orang yang bekerja atau dalam suatu kelompok kerja, kinerja selalu diharapkan bisa senantiasa baik kualitas dan kuantitasnya. Sedangkan menurut Mangkunegara (2017) kinerja adalah "hasil kerja secara kualitas dan kuantitas yang dicapai oleh seorang pegawai dalam melaksanakan tugasnya sesuai dengan tanggung jawab yang diberikan kepadanya".

Menurut Rosidah dan Sulistiyani (2013) "kinerja seseorang merupakan kombinasi dan kemampuan, usaha dan kesempatan yang dapat dinilai dari hasil kerjanya". Rivai (2014) mengemukakan kata kinerja, jika dilihat asal katanya adalah terjemahan dari kata performance yang berasal dari akar kata to perform yang berarti melaksanakan atau menyempurnakan tanggung jawab. Kinerja adalah "hasil atau tingkat keberhasilan seseorang secara keseluruhan selama periode tertentu di dalam melaksanakan tugas dibandingkan dengan berbagai kemungkinan seperti standar hasil kerja, target atau sasaran atau kriteria yang telah ditentukan terlebih dahulu dan telah disepakati bersama".

Berdasarkan pengertian kinerja dari beberapa pendapat di atas, dapat disimpulkan bahwa kinerja merupakan hasil kerja baik kualitas maupun kuantitas yang telah dicapai oleh pegawai, dalam menjalankan tugas-tugasnya sesuai dengan tanggung jawab yang diberikan oleh perusahaan dan hasil kerja yang dicapai disesuaikan dengan standar kinerja pegawai yang berlaku dalam perusahaan.

Menurut Wirawan (2012) kinerja pegawai merupakan hasil sinergi dari sejumlah faktor. Faktor - faktor tersebut yaitu: 1). "Faktor internal pegawai, yaitu faktor - faktor dari dalam diri pegawai yang merupakan bawaan dari lahir dan faktor yang diperoleh ketika berkembang. Faktor-faktor bawaan, misalnya bakat, sifat pribadi, serta keadaan fisik. Faktorfaktor yang diperoleh, misalnya pengetahuan, keterampilan, pengalaman kerja dan motivasi kerja. 2). Faktor-faktor lingkungan internal organisasi, yaitu pegawai memerlukan dukungan organisasi tempat bekerja. Misalnya, 
dukungan sumber daya yang diperlukan untuk melaksanakan pekerjaan, sistem manajemen dan kompensasi. 3). Faktor lingkungan eksternal organisasi, yaitu keadaan, kejadian, atau situasi yang terjadi di lingkungan ekternal organisasi yang mempengaruhi kinerja karyawan".

Penilaian kinerja adalah "proses evaluasi seberapa baik karyawan mengerjakan pekerjaan mereka ketika dibandingkan dengan satu set standar, dan kemudian mengkomunikasikannya dengan para karyawan". (Mathis \& Jackson, 2012). Menurut Dessler (2011), Penilaian kinerja berarti "mengevaluasi kinerja karyawan saat ini atau di masa lalu relatif terhadap standar prestasinya". Penilaian kinerja juga selalu mengasumsikan bahwa karyawan memahami apa standar kinerja mereka, dan penyelia juga memberikan umpan balik, pengembangan, dan insentif yang diperlukan untuk membantu orang yang bersangkutan menghilangkan kinerja yang kurang baik atau melanjutkan kinerja yang baik.

Tujuan penilaian kinerja menurut Rosidah dan Sulistiyani (2013) yaitu: 1). "Untuk mengetahui tujuan dan sasaran manajemen dan karyawan. 2). Memotivasi karyawan untuk memperbaiki kinerja.

3). Mendistribusikan reward dari organisasi yang dapat berupa tambahan gaji atau upah dan promosinya yang adil. 4). Mengadakan penelitian manajemen personalia".

Menurut Gomes (2010), menyatakan bahwa kriteria pengukuran kinerja berdasarkan perilaku yang spesifik adalah sebagai berikut: 1). "Quantity of work, yaitu jumlah tenaga kerja yang dilakukan dalam suatu periode waktu tertentu. 2). Quality of work, yaitu kualitas kerja yang dicapai berdasarkan syarat-syarat kesiapannya. 3). Job knowledge, yaitu luasnya pengetahuan mengenai pekerjaan dan ketrampilannya. 4). Creativeness, yaitu keaslian gagasan yang dimunculkan dan tindakan untuk menyelesaikan persoalanpersoalan yang timbul. 5). Cooperation, yaitu kesediaan untuk bekerjasama dengan orang lain (sesama anggota organisasi). $\quad 6$ ). Dependability, yaitu kesadaran berdisiplin dan dapat dipercaya dalam kehadiran dan penyelesaiaan pekerjaan. 7). Initiative, yaitu semangat untuk melaksanakan tugas-tugas baru dan dalam memperbesar tanggungjawabnya. 8). Personal qualities, yaitu menyangkut kepribadian, kepemimpinan, keramahtamahan dan integritas pribadi”.

\section{METODE PENELITIAN}

Penelitian ini termasuk dalam kategori penelitian asosiatif kausal dengan menggunakan pendekatan kuantitatif. Populasi dalam penelitian ini adalah seluruh karyawan BPJS Ketenagakerjaan Kantor Wilayah Bekasi yang berjumlah 46 orang dan semua dijadikan sampel, karena jumlahnya relatif sedikit. Metode analisa data dengan menggunakan regresi linear sederhana dan berganda.

\section{HASIL PENELITIAN DAN PEMBAHASAN}

\section{Hasil Penelitian}

\section{Uji validitas}

Pengujian validitas ini dilakukan untuk menguji apakah tiap butir pernyataan telah mewakili indikator yang akan diteliti, persyaratan minimum untuk dapat dikatakan valid adalah $r=0,30$. Jadi, apabila korelasi antara butir-butir item pernyataan dengan skor total kurang dari 0,30, maka butiran dalam instrumen tersebut dapat dikatakan tidak valid. Uji validitas dilakukan dengan melihat korelasi antara skor masing-masing item pernyataan dengan skor total. (Sugiyono, 2018). 
Dari perhitungan koefisien korelasi skor tiap butir pernyataan dari 46 responden tentang instrumen motivasi, dengan jumlah 10 pernyataan; instrumen disiplin kerja 8 pernyataan dan instrumen kinerja karyawan 10 pernyataan dengan total skor setiap responden diperoleh hasil $\mathrm{r}$ hitung lebih besar dari $\mathrm{r}$ kritis 0,300 .

\section{Uji reliabilitas}

Pengujian reliabilitas ini dilakukan untuk menguji seberapa jauh hasil pengukuran yang dapat diandalkan secara konsisten. Pada tabel hasil pengujian reliabilitas berikut, diketahui bahwa semua variabel mempunyai alpha di atas 0,6 yang berarti bahwa semua variabel dalam penelitian ini dapat diandalkan.

Tabel 1: Hasil Uji Reliabilitas

\begin{tabular}{lccc}
\hline \multicolumn{1}{c}{ Variabel } & $\begin{array}{c}\text { Cronbach } \\
\text { Alpha }\end{array}$ & $\begin{array}{c}\text { Nilai kritis } \\
(\boldsymbol{\alpha}) \mathbf{5 \%}\end{array}$ & Keterangan \\
\hline Motivasi & 0.622 & 0.600 & Reliabel \\
Disiplin Kerja & 0.758 & 0.600 & Reliabel \\
Kinerja Karyawan & 0.627 & 0.600 & Reliabel \\
\hline
\end{tabular}

Sumber: Data Primer, diolah tahun 2021

Berdasarkan Tabel 1, angka-angka reliabilitas cronbach alpha tersebut tampak bahwa seluruh pernyataan yang ada membentuk ukuran yang reliabel dari mulai motivasi, disiplin kerja, dan kinerja karyawan membentuk ukuran yang reliabel dari masing-masing variabel.

\section{Analisis regresi linear sederhana}

Tabel 2:Pengaruh Motivasi Terhadap Kinerja Karyawan BPJS Ketenagakerjaan Bekasi Kota

\begin{tabular}{lcccccc}
\hline \multirow{2}{*}{ Variabel } & $\mathbf{R}$ & $\begin{array}{c}\mathbf{R} \\
\text { Square }\end{array}$ & Konstanta & $\begin{array}{c}\text { Koefisien } \\
\text { Regresi }\end{array}$ & Sig & $\boldsymbol{\alpha}$ \\
\hline Motivasi & - & 0,645 & 7,310 & 0,833 & 0,000 & 0.05 \\
\hline
\end{tabular}

Pengujian Signifikan

$\mathrm{t}$ hitung $>\mathrm{t}$ tabel $=8,950>2,015$

Keterangan: Variabel Kinerja

Sumber: data diolah 2021

Tabel 2, Nilai koefisien determinasi $\left(\mathrm{R}^{2}\right)$ sebesar 0.645, artinya variabel motivasi memberikan kontribusi sebesar $64,5 \%$ terhadap kinerja karyawan BPJS Ketenagakerjaan Bekasi Kota, sedangkan sisanya sebesar $35,5 \%$ disumbangkan faktor lain.

Persamaan Regresi $\mathrm{Y}=7,310+0,833$ $\left(\mathrm{X}_{1}\right)$
Motivasi berpengaruh positif dan signifikan pada tingkat nyata $99 \%$ terhadap kinerja karyawan BPJS Ketenagakerjaan Bekasi Kota. Koefisien motivasi sebesar 0,833 , artinya jika ada peningkatan motivasi, maka kinerja karyawan BPJS Ketenagakerjaan Bekasi Kota akan meningkat.

Untuk menguji hubungan secara parsial motivasi terhadap kinerja karyawan BPJS Ketenagakerjaan Bekasi Kota signifikan atau tidak, dilakukan pengujian t hitung dibandingkan dengan 
t tabel dengan tingkat $\alpha=0,05$, hasilnya adalah $\mathrm{t}$ tabel $=2,015$. Berdasarkan perhitungan tersebut dapat dinyatakan bahwa nilai $\mathrm{t}$ hitung $=8,950$ dan $\mathrm{t}$ tabel $=$ 2,015 atau $\mathrm{t}$ hitung > $\mathrm{t}$ tabel $(8,950>$
2,015), maka dapat diartikan motivasi berpengaruh signifikan variabel motivasi terhadap kinerja karyawan BPJS Ketenagakerjaan Bekasi Kota.

Tabel 3:Pengaruh Disiplin Kerja Terhadap Kinerja Karyawan BPJS Ketenagakerjaan Bekasi Kota

\begin{tabular}{lcccccc}
\hline \multirow{2}{*}{ Variabel } & $\mathbf{R}$ & $\begin{array}{c}\mathbf{R} \\
\text { Square }\end{array}$ & Konstanta & $\begin{array}{c}\text { Koefisien } \\
\text { Regresi }\end{array}$ & Sig & $\boldsymbol{\alpha}$ \\
\cline { 2 - 7 } & \multicolumn{7}{c}{ Parameter } \\
\hline Disiplin_Kerja & 0,652 & 13,783 & 0,828 & 0,000 & 0.05 \\
\hline Pengujian Signifikan & & & & \\
\hline t hitung > t tabel =9,077 $>2,015$ \\
\hline $\begin{array}{l}\text { Keterangan: Variabel Kinerja } \\
\text { Sumber: data diolah 2021 }\end{array}$
\end{tabular}

Tabel 3, Nilai koefisien determinasi $\left(\mathrm{R}^{2}\right)$ sebesar 0.652 , artinya disiplin kerja memberikan kontribusi sebesar 65,2\% terhadap kinerja karyawan BPJS Ketenagakerjaan Bekasi Kota, sedangkan sisanya sebesar $34,8 \%$ disumbangkan faktor lain.

Persamaan Regresi $\mathrm{Y}=13,783+0,828$ $\left(\mathrm{X}_{2}\right)$

Disiplin kerja berpengaruh positif dan signifikan pada tingkat nyata $99 \%$ terhadap kinerja karyawan BPJS Ketenagakerjaan Bekasi Kota. Koefisien disiplin kerja sebesar 0,828 , artinya jika ada peningkatan disiplin kerja, maka kinerja karyawan BPJS Ketenagakerjaan Bekasi Kota akan meningkat.

Untuk menguji hubungan secara parsial variabel disiplin kerja terhadap kinerja karyawan BPJS Ketenagakerjaan Bekasi Kota signifikan atau tidak, dilakukan pengujian $t$ hitung dibandingkan dengan $t$ tabel dengan tingkat $\alpha=0,05$, hasilnya adalah $\mathrm{t}$ tabel $=$ 2,015. Berdasarkan perhitungan dapat dinyatakan bahwa nilai $\mathrm{t}$ hitung $=9,077$ dan $\mathrm{t}$ tabel $=2,015$ atau $\mathrm{t}$ hitung $>\mathrm{t}$ tabel $(9,077>2,015)$, maka dapat diartikan bahwa disiplin kerja berpengaruh signifikan terhadap kinerja karyawan BPJS Ketenagakerjaan Bekasi Kota.

\section{Analisis regresi linear berganda}

Tabel 4: Pengaruh Motivasi dan Disiplin KerjaTerhadap Kinerja Karyawan BPJS Ketenagakerjaan Bekasi Kota

\begin{tabular}{lcccccc}
\hline \multirow{2}{*}{ Variabel } & Mult. R & $\begin{array}{c}\text { R } \\
\text { Square }\end{array}$ & Konstanta & $\begin{array}{c}\text { Koefisien } \\
\text { Regresi }\end{array}$ & Sig. & $\boldsymbol{\alpha}$ \\
\cline { 2 - 7 } & - & 0,747 & 5,987 & 0,473 & 0,000 & 0.05 \\
\hline Motivasi & & & 0,483 & 0,000 & 0 \\
Disiplin_Kerja & & & & & & \\
\hline Pengujian Signifikan & & & &
\end{tabular}


Tabel 4, dengan menggunakan F signifikan yaitu sebesar 0,000 lebih kecil dari tingkat kepercayaan 0,05, artinya secara bersama-sama motivasi dan disiplin kerja berpengaruh signifikan pada tingkat nyata 99\% terhadap kinerja karyawan BPJS Ketenagakerjaan Bekasi Kota, Nilai Koefisien determinasi $\left(\mathrm{R}^{2}\right)$ sebesar 0.747, artinya motivasi dan disiplin kerja memberikan kontribusi sebesar 74,7\% kepada kinerja karyawan BPJS Ketenagakerjaan Bekasi Kota, sedangkan sisanya sebesar 25,3\% disumbangkan faktor lain yang tidak dibahas dalam penelitian ini.

Persamaan Regresi $\mathrm{Y}=5,987+0,473$ $\left(\mathrm{X}_{1}\right)+0,483\left(\mathrm{X}_{2}\right)$

Motivasi dan disiplin kerja berpengaruh positif dan signifikan terhadap kinerja karyawan BPJS Ketenagakerjaan Bekasi Kota, pada tingkat nyata $99 \%$. Koefisien motivasi sebesar 0,473 artinya jika ada peningkatan motivasi, maka kinerja karyawan BPJS Ketenagakerjaan Bekasi Kota akan meningkat atau sebaliknya dengan asumsi disiplin kerja tidak berubah. Koefisien disiplin kerja sebesar 0,483, artinya jika ada peningkatan disiplin kerja, maka kinerja karyawan BPJS Ketenagakerjaan Bekasi Kota akan meningkat atau sebaliknya, dengan asumsi motivasi tidak berubah.

\section{Pembahasan}

\section{Pengaruh Motivasi terhadap Kinerja Karyawan BPJS Ketenagakerjaan Bekasi Kota}

Hasil penelitian menunjukkan bahwa motivasi mendorong peningkatan kinerja karyawan BPJS Ketenagakerjaan Bekasi Kota. Hal ini menunjukkan bahwa kebutuhnan fisiknya dapat terpenuhi mellaui gaji yang diterima sudah layak, mendapat tambahan bonus tahunan, adanya jaminan hari tua, mendapat perlindungan dalam bekerja, adanya hubungan yang harmonis sesama rekan kerja maupun dengan atasan, mendapat pengakuan atas prestasi kerja dari pimpinan, diberikan penghargaan, pegawai tertarik atas sifat pekerjaan yang menarik sehingga akan mengerahkan kemampuannya. Hasil penelitian ini sejalan dengan penelitian yang dilakukan oleh Habe, (2018), dan Darmanto \& Harahap, (2015) yang menyatakan bahwa motivasi berpengaruh positif dan signifikan terhadap kinerja karyawan, maka hipotesis pertama dapat diterima.

\section{Pengaruh Disiplin Kerja terhadap Kinerja Karyawan BPJS Ketenagakerjaan Bekasi Kota}

Hasil penelitian menyatakan bahwa disiplin kerja mendorong peningkatan kinerja karyawan BPJS Ketenagakerjaan Bekasi Kota. Hal ini dikarenakan bahwa karyawan sesuai dengan waktu yang ditetapkan, dapat menghemat waktu dalam bekerja, karyawan dikerjakan sesuai dengan rencana, selalu mengevaluasi hasil pekerjaan, berani menerima resiko, taat atas jam kerja yang ditetapkan, atas atas perintah pimpinan, dan taat atas prsedur dan metode kerja yang berlaku dalam perusahaan. Hasil penelitian ini sejalan dengan hasil penelitian yang dilakukan Parashakti \& Ekhsan, (2020), dan Susila, (2019), yang menyatakan bahwa disiplin kerja berpengaruh positif dan signifikan terhadap kinerja karyawan, maka hipotesis kedua dapat diterima.

\section{Pengaruh Motivasi dan Disiplin Kerja terhadap Kinerja Karyawan BPJS Ketenagakerjaan Bekasi Kota}

Berdasarkan hasil analisis diketahui bahwa motivasi dan disiplin kerja dapat mendorong peningkatan kinerja karyawan BPJS Ketenagakerjaan Bekasi Kota. Hasil penelitian ini sama dengan hasil penelitian yang dilakukan Ekhsan, (2019), dan Atmojo \& Pradana, (2019), 
yang menyatakan bahwa motivasi dan disiplin kerja berpengaruh terhadap kinerja karyawan, maka hipoteis ketiga dapat diterima.

\section{KESIMPULAN DAN SARAN}

\section{Kesimpulan}

1). Motivasi mendorong peningkatan kinerja karyawan BPJS Ketenagakerjaan Bekasi Kota. 2). Disiplin kerja mendorong peningkatan kinerja karyawan BPJS Ketenagakerjaan Bekasi Kota. 3). Secara bersama-sama motivasi dan disiplin kerja dapat meningkatkan kinerja karyawan BPJS Ketenagakerjaan Bekasi Kota.

\section{Saran}

Dari penelitian yang penulis lakukan dan keterbatasan yang ada, maka penulis memberikan beberapa saran untuk berbagai pihak, yaitu: 1). Pihak BPJS Ketenagakerjaan Bekasi Kota, terus tingkatkan pemberian penghargaan kepada para pegawai yang mempunyai prestasi tinggi, misalnya pegawai dapat memberikan pelayanan yang cepat, baik terhadap pengguna BPJS, sehingga pegawai lebih termotivasi dan dapat meningkatkan kinerjanya. 2). Pihak BPJS Ketenagakerjaan Bekasi Kota, diharapkan harus tetap untuk mempertahankan standar disiplin kerja pegawai yang sudah baik, seperti dalam bekerja menggunakan peralatan kerja, sehingga pegawai yang sudah baik terus dipertahankan. 3). Bagi Peneliti Selanjutnya; Penelitian selanjutnya dapat menambah variabel lain yang dapat mempengaruhi kinerja karyawan, seperti pelatihan dan kompetensi, sehingga penelitian ini akan lebih bervariasi, terutama yang berkaitan dengan kinerja pewagai BPJS Ketenagakerjaan.

\section{DAFTAR PUSTAKA}

Atmojo, Kunto dan Pradana, Erik. 2019. "Pengaruh Motivasi Kerja Terhadap Kinerja Karyawan Pada BPJS Ketenagakerjaan Cabang Sudirman Jakarta". Aliansi: Jurnal Manajemen \& Bisnis. Vol. 14, No. 1 (2019). Hal. 101-111.

Darmanto dan Harahap, R. Hamdani. 2015. "Pengaruh Motivasi dan Disiplin Kerja Terhadap Kinerja Pegawai di Lingkungan Balai Besar Konservasi Sumber Daya Alam Sumatera Utara". Jurnal Administrasi Publik. Vol 3 No. 1, Juni 2015. Hal. 1-20. ISSN: 2088$527 \mathrm{X}$.

Dessler, Gary, 2011. Manajemen Sumber Daya Manusia. Jakarta: Penerbit Indeks.

Ekhsan, Muhamad. 2019. "Pengaruh Motivasi dan Disiplin Kerja Terhadap Kinerja Karyawan PT. Syncrum Logistics". Optimal: Jurnal Ekonomi dan Kewirausahaan. Vol. 13 No. 1 Tahun 2019. Hal. 1-13. ISSN: 1978-2586; EISSN: 2597-4823.

Gibson, M. 2008. Manajemen Sumber Daya Manusia. Cetakan ke dua. Jakarta: Erlangga.

Gomes, Faustino Cardoso. 2010. Manajemen Sumber Daya Manusia. Yogyakarta: Penerbit Andi.

Habe, Hazairin. 2018. "Pengaruh Motivasi dan Disiplin Kerja Terhadap Kinerja Pegawai Pada BPJS Ketenagakerjaan Kantor Cabang Palembang". Jurnal Ilmu Manajemen Saburai. Vol. 4, No. 1, 2018. Hal. 31-38. ISSN: 26217937.

Hasibuan, Malayu S.P. 2017. Manajemen Sumber Daya Manusia. Jakarta: PT. Bumi Aksara. 
Heidjrachman, Ranupandojo, dan Husnan, Saud. 2012 "Manajemen Personalia", Edisi Keempat. Yogyakarta: BPFE UGM.

Ilyas, Yaslis. 2012. Kinerja, teori, penilaian dan penelitian. Jakarta: Pusat Kajian Ekonomi Kesehatan FKM Universitas Indonesia.

Mangkunegara, Anwar Prabu. 2017. Manajemen Sumber Daya Manusia Perusahaan, Cetakan Kesepuluh, Bandung: PT. Remaja Rosdakarya.

Mathis, Robert L. dan John H. Jackson. 2012. Manajemen Sumber Daya Manusia. Edisi Pertama. Jakarta: Salemba Empat.

Moenir, A.S. 2010. Manajemen Pelayanan Umum Di Indonesia. Jakarta: Bumi Aksara.

Nitisemito, Alex S. 2010. Manajemen personalia Manajemen Sumber Daya Manusia. Edisi Ketiga. Jakarta : Ghalia Indonesia.

Parashakti, Ryani Dhayan dan Ekhsan, Muhamad. 2020. "The Effect of Discipline and Motivation on Employee Performance in PT Samsung Elektronik Indonesia". Journal of Reseacrh in Business, Economics and Education. Vol. 2, Issue: 3 June Edition 2020. Pp. 653-660. E-ISSN: 2686-6056.
Rivai, Veithzal, 2014. Manajemen Sumber Daya Manusia untuk Perusahaan : dari Teori Ke Praktik, Edisi Pertama, Depok: Penerbit PT. Raja Grafindo Persada.

Robbins SP, dan Judge. 2008. Perilaku Organisasi. Jakarta: Salemba Empat.

Rosidah dan Sulistiyani, Ambar T. 2013. Manajemen Sumber Daya Manusia. Cetakan Pertama. Yogyakarta: Penerbit Graha Ilmu.

Sastrohadiwiryo, Siswanto. B. 2012. Manajemen Tenaga Kerja Indonesia, Pendekatan Administratif dan Operasional. Jakarta: Penerbit Bumi Aksara.

Sedarmayanti. 2015. Manajemen Sumber Daya Manusia. Bandung: PT. Refika Aditama.

Siagian, Sondang P. 2012. Manajemen Sumber Daya Manusia. Jakarta: Bumi Aksara, Jakarta.

Sugiyono. 2018. Statikstika Untuk Penelitian. Bandung: Alfabeta.

Wirawan. 2012. Evaluasi Kinerja Sumber Daya Manusia Teori Aplikasi dan Penelitian. Jakarta: Penerbit: Salemba Empat. 